dixes provide information concerning the governing body, boards of study, courses in progress which have been recognized and new proposed courses, together with notes about the subjects of courses approved and rejected. The last two appendixes state the examination arrangements and give the decisions of the Council concerning the minimum length of a sandwich course, and conditions for exemption from the first year of the course.

It is evident from the report that the response of technical colleges to the institution of the new award has been excellent. The relatively high rate of rejection for courses offered has been due to the insistence of the Council on the maintenance of fully adequate stendards, a matter of paramount impor- tance in the establishment of the standing of the new award.

Enrolment of approximately one thousand students in the courses recognized up to July of last year represents a substantial and encouraging start to a project which should make a great contribution to meeting the need of Britain for additional technologists. Although the appendixes to the report give considerable detailed information about the position, one vital factor is absent, namely, the distribution of students in relation to their method of satisfying the entrence requirements. In assessing the net gain, the real criterion is that of the sources from which the men are drawn, and it is to be hoped that in future reports this information will be presented.

\title{
SCIENCE EDUCATION IN MALTA
}

$\mathrm{D}^{\mathrm{u}}$ URING Malta's tenth education week, which was organized by the Malta Union of Teachers during May 4-11, 1957, Prof. G. P. Xuereb, dean of the faculty of medicine and surgery in the Royal University of Malta, discussed the place of science in the Maltese educational system.

There is in Malta an acute realization of the fact that changes are necessary in the educational system. The social environment has changed, and educational methods have become unrelated to the social background. There must be an intimate and indissoluble connexion between the pattern of an educational system and the social order for which it is preparing the citizens.

One of the principal causes of the maladjustment between Maltese education and the country's needs lies in the fact that the new scientific knowledge, from which social changes have sprung, is incorporated very imperfectly in the educational system.

The majority of Maltese educated men and women are unaware of the way scientific discovery has shaped society in the past and of the way in which it might change it in the future. Inadequacy of science teachers is imperilling the introduction of the sixth forms in school. The Civil servant is having to face the administration of industry, trade development, public health, statistics, technical education, labour and social services created by forces that his education did nothing to lead him to understand. Everywhere there are improvized methods, because education has given no training.

Scientific studies are not providing the social stimulus and the intellectual training which they should. Judged by the actual hours of teaching, science is still a minor subject in general education. Many teachers still believe that science should not be taught as part of a general education-a belief disguised laconically by the statement that they wish to avoid "premature specialization".

The content of the science courses also leaves much to be desired : the course must be coherent so that everybody realizes the connexion between the successive parts of his science work. Instead of coherence there is a strong bias towards physics-and physics in its most arid form. Chemistry is not yet estab. lished. Biology, far from being taught as the natural history of animals and plants, is 'nature study' and is hurriedly jostled out of the curriculum when it arouses the inborn curiosity of youth. Science is being taught as a collection of laws and facts rather than as a constantly growing body of knowledge with social implications of vital importance. The social repercussions of science are relegated to a fow isolated industrial applications. Briefly, science is presented as a dead body of facts, rather than as a living cultural and social force.

When these boys go to the Royal University, a course in general science is quickly prescribed for the lawyers, legal procurators and theologians of to-morrow. In this course the lecturers ensure that the students learn to believe the authority of the master or text-book and to reproduce the text when asked. These students are confined to the lecture room and are never referred to the laboratories.

The science courses are not much better themselves. Science students spend two years at the University acquiring the basic theoretical and practical know. ledge which they should have more appropriately gathered in the secondary schools. Then, when they are ready to absorb some scientific method, they are passed on to the intermediate course in medicine, pharmacy, architecture and engineering. In medicine considerable time is devoted to introducing them to the sequence of hypothesis followed by experiment or observation and then analysis. Is it surprising that nearly 70 per cent of science students fall by the wayside and that only 30 per cent obtain a medical qualification?

In the past three years the University has taken certain steps to ensure that science is brought into closer relationship with the needs of life. A four-year course for Civil servants has been instituted leading to a diploma in social and political administration. Scholarships in biology, chemistry and physics have been provided, and three Maltese graduates are now at Oxford and London taking the honours school in these specislities before appointment to lectureships in science. The University of Malta will shortly be requiring matriculation in chemistry and in physics or biology from prospective science students. The University has drawn up plans for reform in the course of pharmacy. The libraries have been put on a scientific basis, science laboratories are now completed and funds have been secured for the building of $a$ medical school. These messures are a beginning: they will contribute greatly towards bringing the Maltese educational system into line with a changing social environment. 